\title{
Endemic Burkitt Lymphoma
}

National Cancer Institute

\section{Source}

National Cancer Institute. Endemic Burkitt Lymphoma. NCI Thesaurus. Code C27122.

A clinical variant of Burkitt lymphoma that occurs in equatorial Africa. The Epstein-Barr virus has been detected in all patients. It is the most common malignancy of childhood in this area. 